\title{
A, B, O BLOOD GROUPS AND LEPROSY
}

by John Hsuen, M.в.в.S., EAPEN ThOmas, M.в.в.S., and G. Jesuidian, M.SC.

\section{Schieffelin Leprosy Research Sanatorium, Karigiri P.O., N.A.Dt.}

Of late the role of genetic factors in the development of disease has become a subject of great interest. This study is an attempt to find out whether there is any association between ABO blood groups and the incidence of leprosy.

\section{Materials and Methods}

(1) Study Series: Blood group frequency distribution was determined for a series of 526 leprosy in and outpatients (male and female and all age groups are included) receiving regular treatment at Schieffelin Leprosy Research Sanatorium, Karigiri, South India, during a period of one and a half months (10th July 1962 to 24th August 1962). Almost all the above patients come from nearby villages within a radius of 25 miles from the hospital.

(2) Control Series: Blood group frequency distribution was determined for a series of 1,000 first time blood-donors at the blood bank, Christian Medical College Hospital, Vellore, S. India, situated 10 miles away from the Schieffelin Leprosy Research Sanatorium. Karigiri. These thousand donors consisted of two samples of 500 . The first 500 was taken during the period 24th November 1959 to 1st June 1960 and the second 19th October 1960 to 30th June 1961 with a $n$ interval of about four months between the two samples.

These donors come from the same areas and belong to the same racial group as the leprosy patients and therefore they can be considered as representatives of the general population from which the leprosy patients come. However, it must be mentioned that though the donors composed of both male and female subjects, they are all adults and leprosy has been excluded only by gross examination.

Method: Blood was obtained from the leprosy patients by the finger-prick method (and whenever it was not possible that way, blood was drawn from the vein), and grouped within 48 hours by the slide technique. Great care was exercised by the investigators to avoid technical errors in grouping. No effort was spared in repeating the whole procedure when there was any doubt. Similar technique was employed by the blood bank in grouping the donors.

Leprosy was diagnosed and the type classified by experienced leprologists after a thorough physical examination of the patient. Bacterial Index was done on all the cases, and when there was any 
doubt the diagnosis was confirmed by histopathology. International classification was followed in classifying the cases under study.

\section{Results}

Table 1 shows the frequency distribution of different types of leprosy among the 526 patients.

TABLE 1: Frequency distribution of different types of leprosy among the 526 patients:

\begin{tabular}{l|c}
\hline \multicolumn{1}{c|}{ Type of disease } & No. of cases \\
\hline Lepromatous & 258 \\
\hline Non-Lepromatous: & 268 \\
(1) Tuberculoid & 130 \\
(2) Borderline & 51 \\
(3) Indeterminate & 85 \\
(4) Neural & 2 \\
\hline
\end{tabular}

Table 2 gives the frequency distribution of blood groups among the two series.

TABLE 2: Blood group distribution of 526 leprosy patients and 1,000 first time blood donors.

\begin{tabular}{c|rc|rc}
\hline $\begin{array}{c}\text { Blood } \\
\text { Group }\end{array}$ & \multicolumn{2}{|c|}{$\begin{array}{c}\text { Control Series } \\
\text { No. of cases }\end{array}$} & \multicolumn{2}{|c}{$\begin{array}{c}\text { Study Series } \\
\text { No. of cases }\end{array}$} \\
\hline A & 214 & $(21.4 \%)$ & 130 & $(24.7 \%)$ \\
B & 331 & $(33.1 \%)$ & 123 & $(23.4 \%)$ \\
O & 397 & $(39.7 \%)$ & 257 & $(48.9 \%)$ \\
A B & 58 & $(5.8 \%)$ & 16 & $(3.0 \%)$ \\
\hline TOTAL & 1,000 & $(100 \%)$ & 526 & $(100 \%)$ \\
\hline
\end{tabular}

From Table 2 it can be seen that the distribution of the blood groups in the two series differ $\left(\mathrm{X}^{2}=24.776 \mathrm{P}<0.001\right)$, suggesting an association between the blood groups and the incidence of leprosy. Compared to the control series, the incidence of leprosy is higher in the ' $\mathrm{O}$ ' group and lower in the ' $\mathrm{B}$ ' group in the study series. In the other two blood groups the difference between the two series are not significant.

In Table 3 the blood group distribution among the lepromatous and non-lepromatous patients are shown. 
TABLE 3: Blood group distribution among 258 lepromatous and 268 non-lepromatous patients. The two distributions do not differ significantly: $\left(\mathrm{X}^{2}=2.594 \mathrm{P}>0.05\right)$.

\begin{tabular}{c|rr|rr}
\hline $\begin{array}{c}\text { Blood } \\
\text { Group }\end{array}$ & \multicolumn{2}{|c|}{$\begin{array}{c}\text { No. of cases in } \\
\text { lepromatous }\end{array}$} & \multicolumn{2}{|c}{$\begin{array}{c}\text { No. of cases in } \\
\text { non-lepromatous }\end{array}$} \\
\hline $\mathrm{A}$ & 62 & $(24.03 \%)$ & 68 & $(25.37 \%)$ \\
$\mathrm{B}$ & 68 & $(26.36 \%)$ & 55 & $(20.52 \%)$ \\
$\mathrm{O}$ & 121 & $(46.90 \%)$ & 136 & $(50.75 \%)$ \\
$\mathrm{AB}$ & 7 & $(2.71 \%)$ & 9 & $(3.36 \%)$ \\
\hline TOTAL & 258 & $(100 \%)$ & 268 & $(100 \%)$ \\
\hline
\end{tabular}

Tables 4 and 5 show the distribution of blood group among lepromatous and non-lepromatous patients as compared to that found in the control series.

TABLE 4: Blood group distribution among 258 lepromatous patients and the 1,000 blood donors :

\begin{tabular}{c|rr|rr}
\hline $\begin{array}{l}\text { Blood } \\
\text { group }\end{array}$ & \multicolumn{2}{|c|}{$\begin{array}{c}\text { No. of cases in } \\
\text { control }\end{array}$} & \multicolumn{2}{|c}{$\begin{array}{c}\text { No. of cases in } \\
\text { lepromatous }\end{array}$} \\
\hline A & 214 & $(21.4 \%)$ & 62 & $(24.03 \%)$ \\
B & 331 & $(33.1 \%)$ & 68 & $(26.36 \%)$ \\
O & 397 & $(39.7 \%)$ & 121 & $(46.90 \%)$ \\
A B & 58 & $(5.8 \%)$ & 7 & $(2.71 \%)$ \\
\hline TOTAL & 1,000 & $(100 \%)$ & 258 & $(100 \%)$ \\
\hline
\end{tabular}

TABLE 5: Blood group distribution among 268 non-lepromatous patients and the 1,000 blood donors:

\begin{tabular}{c|rr|rr}
\hline $\begin{array}{c}\text { Blood } \\
\text { group }\end{array}$ & \multicolumn{2}{|c|}{$\begin{array}{c}\text { No. of cases in } \\
\text { control }\end{array}$} & \multicolumn{2}{|c}{$\begin{array}{c}\text { No. of cases in } \\
\text { non-lepromatous }\end{array}$} \\
\hline A & 214 & $(21.4 \%)$ & 68 & $(25.37 \%)$ \\
B & 331 & $(33.1 \%)$ & 55 & $(20.52 \%)$ \\
O & 397 & $(39.7 \%)$ & 136 & $(50.75 \%)$ \\
AB & 58 & $(5.8 \%)$ & 9 & $(3.36 \%)$ \\
\hline TOTAL & 1,000 & $(100 \%)$ & 268 & $(100 \%)$ \\
\hline
\end{tabular}

It is evident from the above tables that the blood group distribution among lepromatous and non-lepromatous patients differ 
significantly from the control series $\left(\mathrm{X}^{2}=9.923 \mathrm{P}<0.02, \mathrm{X}^{2}=\right.$ $21.002 \mathrm{P}<0.001$ respectively). These results are comparable with the overall results given in Table 2 .

In Table 6 the relative incidence of leprosy among ' $\mathrm{O}$ ' group as compared to 'B' group leprosy patients are obtained by simple cross multiplication. Thus, for example, the results for the study series show 121 O's and 68 B's among the lepromatous leprosy patients as against 397 O's and 331 B's amongst the controls:

$$
\frac{121}{68} \times \frac{331}{397}=1.48
$$

So we can say that this sample indicates an incidence of disease of 1.48 in persons of ' $\mathrm{O}$ ' group as compared with 1.00 in persons of group ' $\mathrm{B}$ '.

TABLE 6: Relative incidence of Leprosy in 'O' group as compared to ' $\mathrm{B}$ ' group in the study series:

\begin{tabular}{l|cc}
\hline \multicolumn{1}{c|}{ Type of Leprosy } & \multicolumn{3}{c}{ Relative incidence } \\
O & $:$ & $\mathrm{B}$ \\
\hline Lepromatous & $1.48 \quad:$ & 1 \\
$\begin{array}{l}\text { Non-Lepromatous } \\
\text { TOTAL: Lepromatous and }\end{array}$ & $2.06: 5$ & 1 \\
$\quad$ Non-Lepromatous & $1.74 \quad: \quad 1$ \\
\hline
\end{tabular}

\section{Discussion}

In analysing the results of this study, two facts must be borne in mind.

(1) There is no uniformity between the control and study series in age and sex distribution.

(a) In the study series the ratio of male to female patients is approximately $5: 1$, while that in the control series is approximately $10: 1$.

(b) In the control series the subjects are all adults between the ages of about $20-50$, while patients of all age groups are found in the study series.

(2) Leprosy was excluded in the control series only by a gross examination.

Apart from the above considerations, this study may be of significant value in pointing out the following facts:

(1). That the distribution of blood group in leprosy patients differ significantly from that of the general population, suggesting an 
association between the incidence of leprosy and the ABO blood groups.

(2) Incidence of leprosy is high in ' $\mathrm{O}$ ' group and low in ' $\mathrm{B}$ ' group.

(3) Incidence of leprosy is nearly twice as high in ' $\mathrm{O}$ ' group as compared to the ' $\mathrm{B}$ ' group.

\section{Acknowledgement}

We wish to thank Dr. C. K. Job, M.D., Medical Superintendent, S.L.R. Sanatorium, Karigiri, S. India, who not only made available to us the facilities to carry out this study, but worked with us personally to make this study valuable.

We also wish to thank the staff of S.L.R. Sanatorium and the paramedical workers for their willing co-operation, Mr. Rose of the Blood Bank, Christian Medical College Hospital, Vellore, for providing us with the necessary data. 